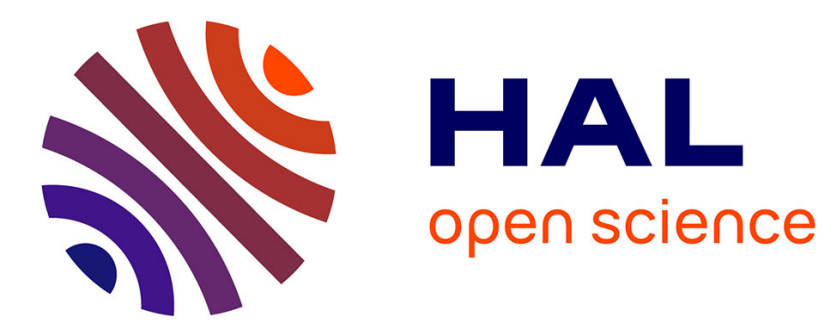

\title{
European External Relations Fields
}

Yves Buchet de Neuilly

\section{- To cite this version:}

Yves Buchet de Neuilly. European External Relations Fields: The Multi-Pillar Issue of Economic Sanctions Against Serbia. 2003. halshs-00269955

\section{HAL Id: halshs-00269955 \\ https://shs.hal.science/halshs-00269955}

Preprint submitted on 3 Apr 2008

HAL is a multi-disciplinary open access archive for the deposit and dissemination of scientific research documents, whether they are published or not. The documents may come from teaching and research institutions in France or abroad, or from public or private research centers.
L'archive ouverte pluridisciplinaire HAL, est destinée au dépôt et à la diffusion de documents scientifiques de niveau recherche, publiés ou non, émanant des établissements d'enseignement et de recherche français ou étrangers, des laboratoires publics ou privés. 


\section{EUROPEAN EXTERNAL RELATIONS FIELDS: THE MULTI-PILLAR ISSUE OF ECONOMIC SANCTIONS AGAINST SERBIA}

Yves Buchet de Neuilly

Centre de Recherche Politique de la Sorbonne (CRPS)

Université Paris 1 - Panthéon-Sorbonne

Observing the uses of economic sanctions is one way to analyze the links between external economic relations and foreign policy ${ }^{1}$. Actors and commentators have for some time deplored the gap between the European economic strength and its political weakness. The series of sanctions imposed against Serbia from 1998 to 1999 are one attempt of the EU to fill this gap and to transform its economic size and weight into a real and effective foreign policy. It was not the first example of EU sanctions (see De Wilde d'Estmael 1998, Nuttall 1992), but it was the first time that EU sanctions were taken autonomously. In other words, these sanctions were unique because they were not simply adopted out of UN Security Council resolutions.

European governments were heavily criticized for their impotence and divisions during the Yugoslav wars. As a result they were prompt to respond rapidly to the troubles in the Serbian province of Kosovo. In addition to diplomatic contacts and mediations, they decided to strengthen their action by using sanctions as a tool. However, the aims of the EU in the beginning of the Kosovo crisis were not as clear as expected. There was minimal consensus that sanctions should in principle be taken, but there were strong dissensions about their effectiveness and scope. The European strategy was not always clear. For example, while EU Foreign Ministers announced tough sanctions, they later signed regulations that did not have any economic impact.

The aim of this chapter is to provide a satisfactory explanation of this apparent contradiction in the EU sanction policy. It argues that the realist analysis is little help, despite the fact that EU common and foreign security policy (CFSP) is generally considered to be an intergovernmental area. In this case, divergences came not from different states but from representatives of the same states. The defence of diverging interests was not the result of individual or bureaucratic disagreements, but rather a consequence of the existence of several autonomous external European bureaucratic spaces or sub-fields ${ }^{2}$ where interests of member states are expressed ${ }^{3}$.

The principle judgement to sanction was always decided in the institutional framework of the CFSP pillar of the EU Treaty. Contrary to common interpretations it was easy to reach a fast agreement under this pillar. On the other hand the decision to implement sanctions under the first EC pillar, was characterized by endless meetings in the Council and a series of tight discussions. The shift of sanctions decisions from pillar two to pillar one led to deep changes in the conditions of negotiation, not only in terms of constitutional structure but also, and 
more decisively, in terms of actor configuration and structural distribution of power both at the member state and at the European level.

This chapter has a number of aims. First, I will briefly summarize the EU diplomatic reaction to the escalating situation in Kosovo (in the spring of 1998) and the use of a sanction strategy generally. I will then highlight the apparent contradictions between the tough political declarations of the European governments and the empty shell of the economic sanctions. Third, to understand this discrepancy, I will show the necessity to identify the relevant space structuration of the EU external relations field. This will lead me, finally, to explain the decision to impose EU economic sanctions as the result of negotiations in relatively autonomous European sub-fields.

\section{SANCTIONS AS A EUROPEAN RESPONSE TO THE KOSOVO CRISIS}

Troubles in the Serbian province of Kosovo intensified in early March 1998. A Kosovar Albanian demonstration was barely repressed by the Serbian police, and at least 80 civilians were killed. For the first time the events in Kosovo raised a unanimous indignation in the international community. The Foreign Ministers of six major diplomatic countries met on 9 March in the framework of the ad hoc Contact Group for the former Yugoslavia. The Contact Group had been set up in 1994 to co-ordinate the positions of the United States, the Federation of Russia, the United Kingdom, France, Germany and the incumbent president of the European Union during the war in Bosnia-Herzgovina (Boidevaix 1997; 64). After the Dayton Agreement, the Contact Group's activities resumed, focussing on the tensions in Kosovo.

On 9 March 1998, the Contact Group condemned the large-scale police action of Serbia and decided to take new measures to increase pressure on the authorities in Belgrade. Ministers called for:

a) UN Security consideration of a comprehensive arms embargo against the Federal Republic of Yugoslavia (FRY);

b) Refusal to supply equipment to the FRY which might be used for internal repression or for terrorism;

c) Denial of visas for senior FRY and Serbian representatives responsible for repressive action by FRY security forces in Kosovo;

d) A moratorium on government financed export credit support for trade and investment, including government financing for privatizations in Serbia. 4

The Foreign Ministers used a stick-and-carrot strategy. They gave the FRY President Slobodan Milosevic ten days to withdraw its special police units and to cease security force action. They threatened to impose further international sanctions and, specifically, to pursue a freeze on the funds held abroad by the FRY and Serbian government. This tough statement was not easily finalized and had to be translated into binding norms before it could have a concrete effect. This was the case in part because the Contact Group had no legal statute and depended on other international or national arenas. 
The attention immediately turned to the UN Security Council where substantive discussions on sanctions began. Drezner (2000) argues that countries often look for broad multilateral support in such diplomatic processes. In New York, however, the divisions expressed during the preparation of the Contact Group statement were more acute. The Russian Federation's hesitation slowed the decision-making process, making the probability of adopting measures within the Contact Group deadline highly unlikely.

In the end, the European governments decided not to wait for the UN Security Council Resolution and instead took autonomous sanctions for the first time (Karagiannis 1999). A draft common position was drawn up by the CFSP Counsellors' working group of the Council and finalized by the Comity of Permanent Representatives (COREPER) in Brussels. Thus, the Contact Group's deadline was met when the Council adopted a common position on restrictive measures against the FRY on the $19^{\text {th }}$ of March. ${ }^{5}$ In line with the Contact Group's recommendations, sanctions consisted of an interdiction to supply equipment for internal repression, a moratorium on government financed export credit support for trade and investment and a visa ban for senior FRY and Serbian representatives.

The next week, on 25 March, the Contact Group noticed some movement in Belgrade's position. ${ }^{6}$ Talks were beginning on the autonomy of Kosovo, and an agreement seemed to be reached on the implementation of an education accord. In the meantime, however, it was feared that nationalist radicalism would rise again following the appointment of Vojislav Seselj, the leader of the ultranationalist Serbian Radical Party, as deputy prime minister . Foreign Ministers decided in the Contact Group to maintain the first restrictive measures. Milosevic was given a new four weeks deadline to avoid further sanctions, and the UN Security Council Resolution 1160, imposing an arms embargo on the FRY, was finally adopted on 31 March. $^{7}$

Tensions continued to be high. There was FRY army activity at the Kosovo border and its police repression intensified. The Contact Group met in Rome on April 29, 'to decide on next steps regarding the increasingly dangerous situation in Kosovo. ${ }^{8}$ Foreign Ministers (excluding Russian) recognized Belgrade's non-compliance to the requirements that they had set out. They decided to freeze the funds of the FRY and Serbian government and threatened to stop new investment in Serbia by 9 May if dialogue was still blocked. The EU rapidly approved the freezing of funds in the common position adopted on the $7^{\text {th }}$ of May. ${ }^{9}$

In a preparation meeting for the G8 Birmingham Summit (London 8-9 May) Foreign Ministers insisted on 'Belgrade's primary responsibility' in the failure to start a dialogue. They also decided (again without Russia) to stop new investment in Serbia. ${ }^{10}$ Meanwhile, Kosovo Albanian leader Ibrahim Rugova and his delegation agreed to meet Slobodan Milosevic in Belgrade on 15 May. The dialogue was supposed to begin with no preconditions, and this new move toward dialogue was welcomed by the withdrawal of the EU's new common position from the agenda. 
It was a short-lived calm. A new level of violence was reached by widespread Serbian security force arson and artillery attacks on villages in Kosovo. The conflict prompted a growing stream of refugees into northern Albania and threatened regional security and stability. In response, the EU foreign Ministers adopted a third common position on sanctions on 8 June. ${ }^{11}$

European governments were increasingly preoccupied by the deteriorating situation on the ground in Kosovo. During the Cardiff European Council (15-16 June) they agreed to adopt further sanctions by imposing a ban on Yugoslav carrier flights between the FRY and the EU. The Council adopted this fourth restrictive measure on 29 June. $^{12}$

There were further sanctions imposed on the FRY during the diplomatic phase of the Kosovo crisis including: refused entry in the member states to persons in the FRY acting against the independent media ${ }^{13}$; an oil embargo ${ }^{14}$; an extension of visa bans; a freeze of FRY funds; a prohibition of export finance; an extension of the investment ban; and a comprehensive flight ban. ${ }^{15}$ None of these restrictive measures had any legal effect on EU economic relations with the FRY, as long as they were not implemented by EC regulations. After fast consultations and reactions from the Foreign Ministers and the CFSP bureaucratic machinery, the decisionmaking process slowed down when it entered into the $\mathrm{EC}$ arenas.

\section{APPARENT CONTRADICTIONS OF THE EU SANCTION POLICY}

A short week was enough to adopt the first EU common position. No more than one meeting was necessary to reach an agreement on the second common position, and the third was also finalized in one meeting after the Council Conclusions. Contrary to common anticipation about diplomatic negotiations, the process was particularly smooth and fast. More difficult talks took place in other arenas, especially in the Contact Group and in the UN. Some EU member states showed little reluctance to follow decisions devised by a 'directory' of the 'big', but there was never a break from the common decision.

Things were completely different at the second stage of the sanction's decision making process. To have a legal impact on economic relations with Serbia, sanctions had to be implemented by the adoption of Community legislation in all areas that fell within European Community competencies. An EC regulation was necessary for each common position, and the second negotiation was far more difficult than the first stage. This is surprising given that there was already unanimity of votes for the common positions and that the EC regulations needed only majority consent. Realistically, however, it took weeks and even months of tireless internal negotiations. As a result the sanctions were deprived of any substance.

As a Dutch diplomat noted,

'in Maastricht, we made the provision that if the Union wants use its economic instruments for sanction measure, then there should be political common position first. But there are two decisions. One is the political decision, which comes first, then we have a decision on the sanctions regulation. And if you look at the sanction regulation negotiation then you see that member states that do agree to the political decision first, 
very often have very different points of view of the actual need for the sanction if they start discussion on the economic measures. There is a huge different of views. We have to negotiate several weeks and very intensely on a piece of paper with very mix arguments, technical arguments, institutional arguments, legal arguments and economic interest arguments. So it's a very complicated field., 16

The Council adopted the first EC regulation on the $11^{\text {th }}$ of May 1998, more than two months after the Contact Group statement and the Community's common position and two weeks after the new Contact Group statement for further restrictive measures. The fourth regulation on the ban of flights that came into force the on 7 September 1998 was even more difficult. It took 83 days from the initial political decision to agree.

TABLE 7.1: ADOPTION TIMING OF THE FIRST ECONOMIC SANCTIONS AGAINST SERBIA

\begin{tabular}{|c|c|c|c|c|c|c|}
\hline $\begin{array}{l}\text { Political } \\
\text { decision }\end{array}$ & $\begin{array}{l}\text { Nature of } \\
\text { economic } \\
\text { sanctions }\end{array}$ & $\begin{array}{l}\text { CFSP } \\
\text { Common } \\
\text { Position }\end{array}$ & Interval & \begin{tabular}{|l} 
EC \\
Regulation
\end{tabular} & $\begin{array}{l}\text { Interval } \\
\text { with } \\
\text { Common } \\
\text { Position } \\
\end{array}$ & $\begin{array}{l}\text { Interval } \\
\text { with } \\
\text { Political } \\
\text { decision }\end{array}$ \\
\hline 9 March & $\begin{array}{l}\text { Embargo on } \\
\text { equipment for } \\
\text { repression }\end{array}$ & 19 March & 10 days & 27 April & 39 days & 49 days \\
\hline 29 April & Freezing of funds & 7 May & 8 days & 22 June & 46 days & 54 days \\
\hline 8 June & $\begin{array}{l}\text { Prohibition of new } \\
\text { Investment }\end{array}$ & 8 June & - & 24 July & 46 days & 46 days \\
\hline 16 June & Ban of flights & 29 June & 13 days & 7 September & 70 days & 83 days \\
\hline
\end{tabular}

The member states who pushed first for fast and tough sanctions were the same to first strongly oppose the adoption of real economic sanctions. The explanation for this rests in part on fears that the sanctions would have adverse consequences for domestic industries. There were complaints from companies 'such as Telecom Italia and Siemens, German textilemakers and governments, including Greece, which was funding construction of a motorway in Serbia. ${ }^{17}$ Greek and Italian Telecom firms had bought 49 percent of the Serb Telecom organism (Srbija), and a Greek consortium had signed two significant co-operation contracts with the Mines of Treptka and Bor in Kosovo. ${ }^{18}$ However, this does not explain why the member states waited until the implementation regulation stage of the sanction decision making process to raise those objections. Before turning to this question, I will show how they managed to reduce the restrictive measures to empty shells.

The main strategy of the member states was to use a legal strike. 'Technical limits' ${ }^{19}$ were the recurrent issue. First, they contested the community competencies, putting forward restrictive definitions of the Community Treaty - mainly Article 133 (former 113). Second, the binding effect of some parts of the regulation was contested. 
A third strategy was to accept only a restricted definition of the scope of sanctions. The wording of the common positions was always very vague and could be clarified in the EC regulation in two opposite ways. For instance, financial sanctions could be limited to a freezing of funds or extended to a suspension of capital flows. The narrow definition adopted in the regulation threw doubt on the effectiveness of sanctions. The Serbian government had, of course, took precautions to transfer its fund outside the EU before the regulation came into force.

Similar problems of interpretation were raised by the notion of 'investments'. An extensive definition could lead to a comprehensive economic embargo and a restrictive definition would result in a lack of economic effects. The Commission proposed that EU companies be forbidden to 'obtain ownership or control, directly or indirectly, of any kind of asset in the Republic of Serbia', including companies, shares, bonds, loans, and intellectual property rights. This provoked a strong hostility among the member states that had tried to water down tough European Commission proposals'. ${ }^{20}$ In the end, they only agreed on an interpretation of investment that prohibits the transfer of funds or financial assets to Serbia. The policy was ineffective, given that there was not such type of investment in Serbia.

Finally, they also contested the applicability of the regulation due to international commitments. The most visible example was the UK failure to enforce the European ban on Yugoslav commercial flights. British officials explained that existing air services agreements made between the UK and Yugoslavia in 1959 took precedence over EU law. Therefore the sanction measures could not apply before a one-year notice period year. ${ }^{21}$

The economic sanctions against Serbia adopted in 1998 had no visible economic impact. They were considerably watered-down during the negotiations of the EC regulation implementation. What explanations account for this seeming U-turn? Did the member states simply change their minds? On the contrary, the explanation lies in the domestic political arena. Scientific literature on bureaucratic politics has shown for thirty years (Allison 1971) that states are not unitary actors. Foreign policy is the result of compromise, conflict, and confusion between officials with diverse interests and unequal influence. Allison's model is certainly helpful, but like its competitors it presents the difficulty of developing reasoning based on a separation between national and international (or European) level games.

\section{RELEVANT SUB-FIELDS OF THE EU EXTERNAL RELATION FIELD}

We could find useful theories offering insights into the preference formation and decision making process in the growing literature on EU public policies and international relations. One of the main contributions to the understanding of EU and international negotiations was the introduction of different levels of analysis. The logic is that policies are not formulated in a single arena but are the consequences of multiple games bargaining. Multi-level game theory and the multi-level governance approach are certainly diverging on many points. Nonetheless, they both share a common interest in the complexity of the EU or international decisional architecture. Negotiations and outcomes are the result of complex linkages between 
the games, and one must take into account what is going on in one game to understand the actions of the main protagonist in the other.

In his well-known article published in 1988, Robert Putnam proposed a convincing articulation of the link between the domestic level and the international level, which he used to explain the outcomes of multilateral bargaining. He focused on the size of the 'win-set' each state is assumed to have, or in other words the set of potential international agreement acceptable at domestic level (Putnam 1988; Evans, Jacobson and Putnam 1993). This model was expanded to encompass the European level for the explanation of the agriculture policy reform in 1992 (Patterson 1997). The EU is presumed to be a third intermediate level between the national and the international arena. It is argued that change in public policy is the result of simultaneous changes in those interlocking levels. The multi-level game theory has been integrated into neo-realist and intergovernementalist approaches of the European construction. The intergovernmentalist theory could not be entirely reduced to a state-centric approach, as it take into accounts the domestic conflict and 'national interests'. Nonetheless, states representatives are considered to be the decisive actors connecting domestic interest and European affairs. $^{22}$

The multi-level governance analysis contests state centric approaches which emphasize 'European level policy-making as the aggregation of domestic interests' (Marks, Hooghe and Blank 1996: 346: see also Kohler Koch 1996). Rather, it is argued that decision-making competencies are shared by state and non state actors - such as supranational institutions and in our case more specifically the European Commission - at different levels as well as subnational actors. Transnational interests could act independently in the European scene, shattering the traditional separation between domestic and international politics. While contesting the prominent and exclusive role of the state, the governance approach of course does not call into question the multi-level analysis. The articulation between multiple arenas is at the heart of this model. Sutcliffe (2000: 291) argues that 'Policy-making responsibility is now shared among a variety of actors at European, national and subnational levels', and attention has been focused on the strategies of alliance between actors of those levels (Ansel, Parsons and Darden 1997).

When distinguishing between the levels of European games, researchers very often focus exclusively on the separation between a European level and a national or domestic level (Moravcsik 1998, Evans, Jacobson and Putnam, 1993). They explore the relation between domestic politics and EU foreign policy (Hill 1996) and the changes in national foreign policy structure caused by the development of the CFSP (Smith 2000). Although there are fundamental differences between multi-level game and multi-level governance theories, both encompass a similar pattern of level division: a vertical territorial level distinction. On the other hand, the theories offer divergent explanations for the articulation between the levels and on the actors involved in both different arenas.

But in the sanction case, such levels of division are little help. The apparent contradiction of the EU sanction policy could not be attributed to the complex relations between member states, EU and international level negotiations, as far as those contradictions appeared between decisions drawn up at the same territorial level. A territorial division of the games 
could be relevant for the explanation of each decision process (the CFSP common position and the EC Regulation) but not to understand the links and differences between those decisions.

In one recent article, Sarah Collinson (1999) combined the vertical game division of Putnam's theory with the horizontal division of James Rosenau's 'issue-systems' model. This concept allows her to 'steer the analysis to focus on the interaction of overlapping systems and subsystems of political action that form around specific issues or combination of issues' (Collinson 1999: 207). Therefore, attention could be turned to the analysis of 'overlapping and interacting policy arenas within the EU governance system' and the effects on the policy process and the outcomes of this interaction. This distinction of overlapping policy arenas and the analysis of their relations to each other are particularly appropriate in the external relations' field. The next step is to identify the distinctive systems. Collinson suggests two different and tying ways to locate them: one is to focus on the legal and institutional framework; the second is to focus on the issue.

The constitutional structure is certainly the most visible sign of distinction between the external EU policy areas. The Maastricht Treaty is divided into three pillars with important legal distinctions. Commercial and development policy fall under Article 133 (former 113) and Article 310 (former 238), while foreign and security policy is defined by pillar two provisions. In the first pillar, the European Commission has a monopoly of initiative and leads the implementation of decisions often taken under the rule of majority. In the second pillar, member states keep their faculty to initiate the negotiations and to block the decisions in a socalled intergovernmental system. Of course, the decision making process can not be reduced to a legalistic view and we should always be aware of the variation of power in each area. But it seems quite obvious that the first and second pillars are dealing with different issues and therefore are constitutive of two separate issue-systems, including several narrowly defined issue-systems or issue-'subsystems' - such as external commercial policy or development policy (Collinson 1999: 213).

The two systems or subsystems may have the same issue on their agenda (Rosenau 1990) and the way an issue is handled in one system may have repercussions on its handling in the other system. The political use of an economic instrument, as is the case for economic sanctions, is particularly interesting as far as it spreads some light on the autonomy and interdependency of two important EU external sub-fields. The sanctions were at stake at both first and second pillar levels. One similarity between the two pillars was the effect that CFSP decisions (the sanctions common positions) had on EC agenda setting (the necessity to adopt implementing EC regulations). At the same time this sanction process shows the autonomy of the two subfields allowing strong differences in the policy outcomes (ie tough sanctions in the first pillar and very weak sanctions in the second pillar).

Such divergent policy outcomes are generally attributed to differences of constitutional structures. A widely accepted hypothesis about the effect of institutional rules in the Council is that, under the rule of unanimity voting, the common position eventually reached is the lowest common denominator. By contrast, the majority rule has the effect of mitigating the extreme position (Garrett and Tsebelis 1996; Meunier 2000). In the sanction case, the 
institutional hypothesis does not work. Tough economic sanctions were easily adopted under the rule of unanimity in the CFSP pillar and weak economic sanctions were more difficult to adopt under the majority rule of the EC pillar. Common positions were not the voice of the more conservative EU member states. Greece, for example, was very reluctant but did not threaten to use its veto right in the CFSP pillar. Furthermore EC regulations under qualified majority voting in the first pillar were radically different than the proposal originally made by the Commission, and were limited to the lowest common denominator.

These facts either undermine the link between institutional rule and the outcome of Council decisions, or mean that institutional rules are less decisive than other variables to explain the variation of degree in EU decisions. The second is more plausible explanation. because voting rules do not fully help us understand the EU's decision to reduce the scope of economic sanctions against Serbia. One of the tacit assumptions of an institutional explanation would have been that the national interest of a state would be the same in all areas. But in our case, the representatives of the same states pushed for a fast adoption of tough sanctions when they took part in the negotiation of the CFSP common position. s. However, they were strongly opposed to any substantial sanction when it came to the adoption of EC regulations. . The problem came not precisely from the multiplicity of national interests but from the diversity of sub-fields, where national interest had to be expressed. This distinction is fundamental. The diverging interests of the member states over time can be attributed to the existence of two different sub-fields, one generally referred to as traditional foreign policy and the other as external economic policy. The differentiation is not caused by the institutional structure of the Maastricht Treaty. If both were under the rule of EC pillar they would remain autonomous, just as the common agriculture policy is autonomous from education and culture policy. In this case, the institutional properties of the pillar do not explain the distinction between the spaces of external relations. They are only signs. The pillar structure of the Treaty is, above all, an institutional translation at one time of a pre-existing structural differentiation.

I do not deny that institutional structures have consequences on the negotiation process and partially explain the outcomes. The argument, however, is that we can not attribute policy system differentiation only to the institutional differences. Otherwise, we need to explain the diverging positions of the member states in the two sub-fields by institutional arguments.

One other significant sign of structural change between the CFSP diplomatic sub-field and EC economic relations' sub-field was the mobilization capacity of interests. This change enables us to explain why private or public industrial interests are linked to domestic or transnational constraints during the EC regulation negotiations and not during the CFSP common position negotiations. Within a sub-field, an issue (for example economic sanction) may or may not be an activator for domestic or transnational interests. Strategies of private or public industrial interests, which seek to gain access to the decision-makers, highlight the line of differentiation between the relevant sub-fields of the EU external relations' field. Multiple channels of contact were used simultaneously at the national and the European level. These channels were used mainly when negotiating the EC implementation regulation, because this is where they had the greatest opportunity to exert influence. 
EU economic sanction decisions are issues that are simultaneously localized in two EU external spaces: foreign policy and external economic relations. It is essential to identify this horizontal field division in order to explain how it is possible at the same time to adopt both strong and weak measures.

\section{EXPLAINING THE EU SANCTION DECISIONS}

Why has the European Union not consistently been able to transform its economic size and weight into a real and effective foreign policy? The question is on everyone lips and it surfaces on the agenda of many intergovernmental conferences for the revision of the European Treaties. The failure of the European foreign policy is generally put down to the institutional framework of its decision making process. Unlike external economic action, the Common Foreign and Security Policy (CFSP) remains in the hands of the member states in the intergovernmental second pillar of the Maastricht Treaty. It is certainly true for European security policy, as it exists in the European Security and Defence Policy (ESDP). However, European foreign policy is less clear. As noted above, the watering-down of sanctions does not originate in the constitutional pillar structures.

The change of sanctions was first and foremost a change in the sub-field. It was not necessarily a change of players, ${ }^{23}$ or a change of institutions. Rather, differences between the foreign policy sub-field and the external economic relations' sub-field are structural. The positions and power of the actors are different, as are effective means of action, expectations and concerns. In the first space, they negotiate the economic sanctions as a political issue, bearing in mind their impact on the diplomatic arena. In the second space, sanctions are negotiated mainly as an economic issue, considering their impact on trade and financial relations between the EU and the FRY. Political consequences are the priority in the CFSP sub-field, whereas economic consequences are the principal concern in the external economic relations' sub-field.

According to Robert Pape (1997: 95), what policymakers 'most want to know [is] when the strategy of economic sanction can change another state's behaviour without resorting to military force'. The change of state behaviour is a political change, which is to be expected in the diplomatic sub-field. It is not an economic change. The political and economic impact of sanctions is not necessarily connected. An economic sanction could have diplomatic effects without any economic effect. Talks between Milosevic and Rugova began just after the announcement of new economic sanctions and before the adoption of the implementation measure of the previous sanctions. These economic sanctions were a success, but they were not implemented and therefore could not have any economic impact. The success of the policy was purely political, which is acceptable as long as the real economic impact was not directly connected to the political impact. Economic sanctions may have political costs for the target with or without economic costs. However, neither the Contact Group nor the UN Security Council's aims can be discussed exclusively in economic terms. 'Resonant norms' (Drezner 2000: 81), defined as a legitimate vision of action shared by the diplomatic community, also factor into the analysis. 
A priority in the foreign relation sub-field is not necessarily a priority in the external economic sub-field. In the classical diplomatic space, the timing is very important. One should react quickly to any event in the international scene. Deadlines are fixed and respecting them gives credibility. To exert presssure on Milosevic, diplomats and Foreign Ministers fixed very short deadlines ( 9 days to withdraw security forces, etc.). Considering the strong reservations of the Russian Federation, it was a too short a deadline for a UN security resolution. In the absence of consensus the European and American governments decided, each one for their part, to adopt the sanctions. The first EU common position on restrictive measures against the FRY met the deadline. This was in itself a success. According to the former US Foreign Secretary of State Madeline Albright, it enabled the western security community to 'maintain credible pressure on Belgrade to end repression and restore autonomy (in Kosovo).' ${ }^{24}$ Setting a deadline and upholding it signalled diplomatic determination, the effects of which were noticeable during the diplomatic negotiations. The situation in the economic implementation sub-field was different. The interval between the political decision and the economic implementation was far more important. There was pressure to accelerate the negotiation process, but the expectation for fast action could not overcome the defence of economic interests. The hierarchy of priorities was not the same in this sub-field.

The identification of the two autonomous sub-fields is not sufficient to explain why the EC regulation was hard to negotiate when it was easy to adopt the CFSP common position. Given that the preferences of the principle member states were aligned in both sub-fields, why was it so difficult to adopt the EC regulations? Here we should introduce the constitutional variable in the analysis. The move from the second pillar to the first pillar comes with a change of the relative power position in the space. This change lies partly on the redistribution of institutional resources. For the European Commission, the most sensible evolution occurred. Weak and often marginalized in the CFSP sub-field, the Commission has a strong position in the EC sub-field. Its formal monopoly of initiative gives it the means to formulate strong proposals, allowing the Commission to play a major role in the sanction policy. Tough economic sanctions were not acceptable for the representatives of the principal member states, but they had to wait for the official adoption of the Commission proposal. In addition, they needed to find unanimity on all points to overcome the Commission's text.

\section{CONCLUSION}

External economic relations is a well established EU competence, while foreign policy is still considered as intergovernmental matters. The use of economic pressure for political goals is one of the most visible overlaps between these areas. Many authors have shown the complexity of the 'hydra of European Foreign Policy' (Hill and Wallace 1996: 2; Holland 1997), but they tend to focus almost exclusively on the states, trying to understand their strategies and interests and whether they act under CFSP or community arenas (adding the European Commission in the second case). In order to understand the role of the EU in international relations and its capacity to lean on its economic power to increase its political weight, it is useful to identify the relevant spaces of the external relations' field. We could move our attention from the interaction between the national and European levels to the relations between political and economic bureaucratic sub-fields. 
During 1998, while Foreign Ministers and EU diplomats were engaged on a test of strength with the Yugoslav government, ministries and bureaucrats interested in the EU's economic interest were trying to minimize the economic cost of the retaliation against Milosevic. What appears as a contradiction of the EU foreign policy was only the effect of the differentiation of the sub-fields of the EU external relations' field. Diplomatic and external economic policies could peacefully coexist and develop in different directions. It is only in situations where calls for more consistency are made that, the divergent outcomes of the structurally differentiated EU external relations field becomes a problem. Expectation for consistency is one way of thinking the competence's struggles (between COREPER and Political Comity) that often characterize interpillar relations (Ginsberg 1997). However, this was not the case during the first diplomatic stage of the Kosovo crises. Economic sanctions were an issue that crossed over into the two sub-fields, but the horizontal repercussion was essentially limited to the impulse of the negotiation in the EC external economic space after the adoption of the CFSP common positions. Thus, there was every chance that the actors involved in the two distinctive and relatively autonomous sub-fields of the EU external relations would produce dissonant strategies.

The purpose of this chapter was not to explain why tough sanctions were adopted in the second pillar and empty sanctions in the first pillar (although this could have raised questions about the costs of sanctions in the first pillar where they were probably more specific than in the second pillar) but to explain why the same states could adopt both tough and empty sanctions at the same time. These 'contradictory' outcomes are puzzling as long as we confront activities from the two pillars using a single framework. In other words, we are puzzled if we look at what is happening in the economic external relations field using political diplomatic lenses or when there are crossed field feedbacks - for example, if a diplomat contest the EU political sanction strategy arguing that economic measures have no economical impact. In practice, it is generally not necessary for states to have consistent economic and political interests. Governments can, without difficulty, manage the diversity of their interest as far as they do not cross over into a single issue area. A theoretical approach based on the structural notion of 'fields' offers us the possibility to identify different areas where states (or the EU) are acting out their specific social properties. In our case, the two sub-fields correspond to an institutional particularity of the European Union: the pillar structure. Thus, in order to understand the multi-pillar process, it is important to take into account the differences of logics of actions that lead to specific interest framing.

\section{References}

Allison G. T. Essence of Decision: Explaining the Cuban Missile Crisis, New York, Harper Collins, 1971: 338.

Ansell C. K., Parsons C A., Darden K A. 'Dual Networks in European Regional Development Policy', Journal of Common Market Studies, 1997, 35(3): 347-372.

Boidevaix F. Une diplomatie pour l'Europe. Le Groupe de Contact Bosnie, Paris, Fondation pour les études de défense, $1997: 192 \mathrm{p}$.

Bourdieu P. and Wacquant Loïc J. D. An Invitation to Reflexive Sociology, Chicago: The University of Chicago Press, 1992: 332. 
Buchet de Neuilly Y. The chaotic path of European Foreign Policy: Interdependences, competitions, crossed exchanges and institutionalisation process in a world of differentiated fields, $\mathrm{PhD}$ dissertation, University of Paris 1 - Panthéon-Sorbonne, 2001:649.

Collinson S. 'Issue-systems', 'multi-level games' and the analysis of the EU's external commercial and associated policies: a research agenda', Journal of European Public Policy, 1999, 6(2): 206-24.

De Wilde d'Estmael T. La dimension politique des relations économiques extérieures de la communauté européenne. Sanctions et incitants économiques comme moyens de politique étrangère, Bruxelles, Etablissements Emile Bruylant, 1998 : 445.

Drezner D. W. 'Bargaining, Enforcement, and Multilateral Sanctions: When Is Cooperation Counterproductive?', International Organization, 2000 54(1): 73-102.

Evans P. B., Jacobson H K. and Putnam R D. (eds.), Double-Edged Diplomacy, Berkeley, Los Angeles and London: University of California Press, 1993: 490.

Garett, G. and G. Tsebelis 'An Institutional Critique of Intergovernmentalism', International Organization, 1996 50(2): 269-99.

Ginsberg R. 'The EU's CFSP: the Politics of Procedure', in M Holland (ed.), Common Foreign and Security Policy. The Records and Reforms, London and Washington: Pinter, 1997: 12-33.

Hill C. and W. William 'Introduction. Actors and actions', in Christopher Hill (ed.), The Actors in Europe's Foreign Policy, London: Routledge, 1996: 1-16.

Holland M. (ed.) Common Foreign and Security Policy. The Records and Reforms, London and Washington: Pinter, 1997: 210.

Karagiannis S. 'Sanctions internationales et droit communautaire. A propos du règlement 1901/98 sur l'interdiction de vol des transporteurs yougoslaves', Revue trimestrielle de droit européen, 1999 35(3): 363-94.

Kohler-Koch B. 'Catching up with change: the transformation of governance in the European Union', Journal of European Public Policy, 1996 3(3): 359-80.

Marks G., Hooghe L. and Blank K. 'European Integration from the 1980s: State-Centric v. Multi-level Governance', Journal of Common Market Studies, 1996 34(3): 341-78.

Meunier, S. 'What Single Voice? European Institutions and EU-US Trade Negotiations', International Organization, 2000 54(1): 103-35.

Moravcsik, A. The Choice for Europe: Social Purpose \& State Power from Messina to Maastricht, Ithaca, New York: Cornell University Press, 1998: 514.

Moravcsik, A. 'Preference and Power in the European Community: A Liberal Intergovernmental Approach', Journal of Common Market Studies, 1993 31(4): 473-524.

Nuttall, S. European political co-operation, Oxford: Clarendon Press, 1992: 342.

Pape, R. 'Why economic sanctions do not work', International Security, 1997 22(2): 90-136.

Patterson, L. A. 'Agriculture policy reform in the European Community: a three-level game analysis, International Organization, 1997 51(1): 135-65.

Putnam, R. D. 'Diplomacy and Domestic Politics: The Logic of Two-Level Games ", International Organization, 1988, 42 (3): p. 428-460.

Rosenau, J. Turbulence in World Politics: A Theory of Change and Continuity, Princenton, N.J.: Princeton University Press, 1990: 480.

Smith, M. E. 'Conforming to Europe: the domestic impact of EU foreign policy cooperation', Journal of European Public Policy, 2000 7(4): 613-31.

Sutcliffe, J. B. 'The 1999 reform of the structural fund regulations: multi-level governance or renationalization?', Journal of European Public Policy, 2000 7(2): 290-309. 


\footnotetext{
${ }^{1}$ This chapter is based on the empirical materiel gathered for my $\mathrm{PhD}$ thesis (Buchet de Neuilly 2001). including thirty one recorded and transcribed interviews and dozens of informal discussions with actors in Brussels (in the European Commission, the General Secretariat of the Council and Permanent representations of Member States), in Paris (in the ministry of foreign affairs and the general secretariat for interdepartmental coordination)- as well as participant observation as a stagiaire to the CFSP Counselor of the Commission, from March to July 1998, which afforded me the opportunity to attend many Council group meeting where sanctions were negotiated.

${ }^{2}$ A field or a sub-field is a configuration 'of objective relations between positions. These positions are objectively defined, in their existence and in the determinations they impose upon their occupants, agent or institutions, by their present and potential situation (situs) in the structure of the distribution of species of power (or capital) whose possession commands access to the specific profits that are at stake in the field, as well as by their objective relation to other positions (domination, subordination, homology, etc.)' (Bourdieu and Wacquant, 1992: 97).

${ }^{3}$ In the sanction case these are the diplomatic sub-field and the external economic relations sub-field.

${ }^{4}$ Contact Group Meeting, Statement on Kosovo, London, 9 March 1998, http://www.ohr.int/docu/d980309a.htm.

${ }^{5} 2075^{\text {th }}$ Council meeting - Justice and Home Affairs, Brussels, 19 March 1998, C/98/73. Common position of 19 March 1998 on restrictive measures against the Federal Republic of Yugoslavia, OJEC, L 95, 27/03/98, p. $1-2$.

${ }^{6}$ Contact Group Meeting, Statement on Kosovo, Bonn, 25 March 1998, http://www.ohr.int/docu/d980325b.htm.

${ }^{7}$ Resolution 1160, adopted by the Security Council at its $3868^{\text {th }}$ meeting, on 31 March 1998, S/RES/1160 (1998).

${ }^{8}$ Contact Group Meeting, Statement on Kosovo, Rome, 29 April 1998, http://www.ohr.int/docu/d980429a.htm.

$92091^{\text {st }}$ Council meeting - Industriy, Brussels, 7 May 1998, PRES/98/129. Common position of 7 May 1998 concerning the freezing of funds held abroad by the FRY and Serbian Government, 98/326/CFSP.

${ }^{10} \mathrm{http} / / /$ birmingham.g8summit.gov.uk/forfin/foreign.shtml.

${ }^{11} 2104^{\text {th }}$ Council meeting - General Affairs - Luxembourg, 8/9 June 1998, PRES/98/190. Common position of 8 June 1998 concerning the prohibition of new investment in Serbia, 98/374/CFSP.

${ }^{12}$ 2111th Council meeting - General Affairs - Luxembourg, 29 June 1998, PRES/98/227. Common position of 29 June 1998 concerning a ban on flights by Yugoslav carriers between the Federal Republic of Yugoslavia and the European Community, 98/426/CFSP.

${ }^{13}$ Common position of 14 December on restrictive measures to be taken against persons in the Federal Republic of Yugoslavia acting against the independent media, 98/725/CFSP.

${ }^{14}$ Common position of 23 April 1999 concerning a ban on the supply and sale of petroleum and petroleum products to the Federal Republic of Yugoslavia, 1999/273/CFSP.

${ }^{15}$ Common position of 10 May 1999 concerning additional restrictive measures against the Federal Republic of Yugoslavia, 1999/318/CFSP.

${ }^{16}$ Interview, Brussels, April 2000.

17 "Discord erodes force of Serbia sanctions", European Voice, 16-22 July 1998.

${ }^{18}$ AFP, Athena, 11/06/98.

${ }^{19}$ Interview with a French high civil servant, general secretariat for interdepartmental coordination (SGCI), Paris, April 2000.

20 "Discord erodes force of Serbia sanctions", European Voice, 16-22 July 1998.

${ }^{21}$ Reuters, Brussels, September 10.

22 "The prospects for international agreement will depend almost entirely on the configuration of societal preferences; in negotiations, governments have little flexibility in making concessions, proposing linkages, managing adjustment or otherwise settling on the 'lowest common denominator'. International agreement requires that the interests of dominant domestic groups in different countries converge ; where they diverge, coordination precluded.' (Moravscik 1993: 487)

${ }^{23}$ Foreign Ministers and CFSP Counselors participate in the two games, but in the individual capitals there were quite different actors involved.

${ }^{24}$ Inter Press Service, Bonn, 25 Mars 1998, http://www.oneworld.org/ips2/mar98/20_58_081.html.
} 